\title{
Comparison of Compressive Strength Value of Concrete Using Pumice Sand with Ordinary Sand as Fine Aggregate
}

\author{
$N{ }^{\prime}$ Man $^{1 *}$, Abdul Gaus ${ }^{2}$ Mufti Amir Sultan ${ }^{2}$ \\ ${ }^{1}$ Master Degree Program, Department of Civil Engineering, Faculty of Engineering, Universitas Khairun, Ternate, Indonesia \\ ${ }^{2}$ Department of Civil Engineering, Faculty of Engineering, Universitas Khairun, Ternate, Indonesia
}

\begin{abstract}
In this study, the method according to the Indonesian National Standard (SNI) was applied. The objects test in the form of cylindrical concrete in which the fine aggregate was pumice sand and ordinary sand. The test objects made were tested for compressive strength. There were 6 test objects made in this study with a size of $15 \mathrm{~cm} \times 30 \mathrm{~cm}$. In detail, 3 test objects were made of pumice sand, while the other 3 test objects were made of ordinary sand. The coarse aggregate for all test objects was crushed stone. The result shown the use of pumice sand as a substitute for fine aggregate can reduce the compressive strength of concrete by $23.53 \%$. However, it can reduce the weight of concrete by $7.03 \%$. Therefore, for construction that prioritizes weight, concrete with pumice sand as fine aggregate is better compared to concreate with ordinary sand as fine aggregate.
\end{abstract}

Keywords: Compressive Strength, SNI, Pumice Sand

\section{Introduction}

Along with the development in urban areas that trigger an uncontrolled land conversion and the formation of new inundation areas that have a negative impact on road conditions, traffic activities, and the lives of surrounding communities, it is necessary to plan an integrated drainage system to reduce the negative impacts of this development [1].

Drainage has an important role as a road supporting structure. A good drainage system can help reduce the possibility of flooding, land surface changes, soil erosion, and damage to existing roads and buildings. By considering the way drainage is formed, there are two types of drainage: natural drainage and artificial drainage. In addition, from the construction studies, drainage is divided into closed drainage and open drainage [2]. With the increasing number of environmental problems related to the arrangement and modeling of the drainage system, a new concept of drainage development has emerged, for example, environmentally friendly drainage or commonly known as the eco-drain model, which is an effort to manage excess water by absorbing as much water as possible into the soil naturally or drain water into the river without exceeding the capacity of the river [3].

Several concepts can be applied in environmentally friendly drainage. For example, rainwater can be absorbed into the soil, drained to artificial reservoirs, or channeled to natural water bodies. It can also be flowed back to the nearest river without increasing the burden on the river. Furthermore, developing a polder system, building interceptor channel sluice gates, and making conservation ponds in urban areas, settlements, agriculture, or plantations are also environmentally friendly drainage efforts. Besides, applying the infiltration well method is a practical way for making environmentally friendly drainage, in which rainwater that falls on the roofs of housing or certain areas is drained into the well. This infiltration well is only devoted to rainwater so that people should not channel household wastewater into the wells [4].

Currently, the concept of drainage development is experiencing very rapid development, from drainage that only uses masonry to precast reinforced concrete drainage. As a result, the drainage which was originally in a trapezoidal ditch shape becomes a U-ditch shape (known as U-ditch drainage). Besides, the narrower land area makes the drainage plan directed from an open channel (an old concept) to a closed channel by utilizing the top of the channel to become a sidewalk for pedestrians [5].

Because of many excavations carried out for the installation of utility networks, such as telephone cables, freshwater pipes, pay television cables, and telecommunications cables, it requires a large land area and interferes with community activities on the highway. Therefore, innovation is highly needed in utilizing existing drainage channels as a medium for laying the utility network because the existing drainage channels have not been able to accommodate these needs. For this reason, this needs a precast drainage channel (U ditch) which is given a hole as a place for the placement of the cables or pipes [6]. 


\section{Literature Review}

Perforated reinforced concrete beams have a disadvantage, namely, the ability of the beam to withstand loads is reduced by about $5 \%$ compared to intact beams without holes. Although the decrease in beam capacity is quite small and insignificant, the reduction in beam stiffness must be considered because it is highly significant. The greatest weakening occurs in beams with holes in the maximum bending area so that it is necessary to avoid making holes in the middle of the beam. If this has to be done, it is necessary to do reinforcement around the hole to avoid premature destruction of the hole due to loading [7].

Tidore, a city located in North Maluku Province, has abundant reserves of pumice sand. This potential can be maximized and used as an alternative to environmentally friendly natural materials in concrete mixtures for road drainage works [8].

Pumice sand as a fine aggregate material has been widely used in a cement brick mixture because it has a better structure than beach sand or river sand [9]. The specific gravity of pumice sand is also lighter than normal fine aggregate, which ranges from 1.6 to 3.2. As a result, if pumice sand is used as a concrete-forming material, the weight of concrete using this pumice sand can be lighter than the weight of concrete using other fine aggregates. In other words, pumice sand is very suitable for use in earthquake-prone areas, such as North Maluku [10][11].

\subsection{Drainage}

As stated by Suripin, drainage is a channel of water on the surface or under the ground, either naturally formed or man-made formed. Drainage can refer to trenches at the ground level or culverts at the underground level. Drainage plays an important role in regulating water supply for flood prevention. Drainage has the function of flowing water. In general, drainage is defined as a series of water structures that serve to reduce and/or remove excess water from an area so that the land can be used optimally. Drainage is also defined as an attempt to control groundwater quality in relation to sanitation [12].

\subsection{Concrete}

Concrete is a composite material (mixture) of several materials, such as cement, fine aggregate, coarse aggregate, water, and often added various additional materials like chemicals, fibers, or non-chemical waste materials in a certain ratio. The basic materials for forming concrete can essentially be grouped as active materials and passive materials The active materials consist of cement and water which will later serve as adhesives/binders, while the passive materials are fine aggregates and coarse aggregates which serve as fillers [13].

Precast concrete is a structural construction technology in which the constituent components are firstly cast in a special place (off-site fabrication).
Sometimes, these components are firstly assembled and put together (pre-assembly). After that, they are installed at the installation site. Therefore, this precast system will be different from monolith construction, especially in the planning aspect which depends or is determined by the method of implementation of the fabrication, integration, and installation. Furthermore, it is also determined by the technical behavior of the precast system in terms of how to connect the joint components [5].

\subsection{Pumice Sand}

Pumice sand is one type of material with a small specific gravity (fine aggregate) so that the weight of the pumice sand grains is relatively light. Basically, pumice sand comes from pumice stones that have been crushed so that it has smaller grains. Pumice is a stone with the main characteristics of being light in color and very porous. Pumice is a type of igneous rock formed from an explosive volcanic eruption. This rock is also known as silicate volcanic glass because it contains foam made of glass-walled bubbles. Pumice is most widely used as a lightweight concrete aggregate and an abrasive material in various industrial products. Pumice has a high porosity so that this kind of stone can float on water [14].

\subsection{Compressive Strength}

Compressive strength is the value of materials in holding a load. The compressive strength of concrete is measured in load per unit area, in which the concrete that becomes the test object is given load with a certain compressive force produced by the press machine until the test object crumbles [15]. The compressive strength of concrete is the most important property for determining the quality of concrete compared to other properties. The compressive strength of concrete can be adjusted by setting the ratio of cement, coarse aggregate, fine aggregate, and water. The ratio of water and cement must be highly considered. A certain amount of water is required to provide a chemical action in hardening concrete. However, excess water may increase workability but decrease strength [16].

In the latest Indonesian national standard published in 2011, the strength of the concrete is measured in the compressive strength of a test object $\left(f^{\prime} c\right)$ in the form of a concrete cylinder with an MPa unit. The test object has a diameter of $15 \mathrm{~cm}$, has a height of $30 \mathrm{~cm}$, and is 28 days old. The test objects used for compressive strength in this study can be seen in Figure 1.

The value of the compressive strength of the test object is calculated using the following equation.

$$
f^{\prime} c=\frac{p}{A}
$$

Where: $f^{\prime} c$ is the compressive strength of the test object $(\mathrm{MPa}), \mathrm{A}$ is the cross-sectional area of the test object $\left(\mathrm{mm}^{2}\right)$, and $\mathrm{P}$ is the highest load read on the testing machine $(\mathrm{N})$. 


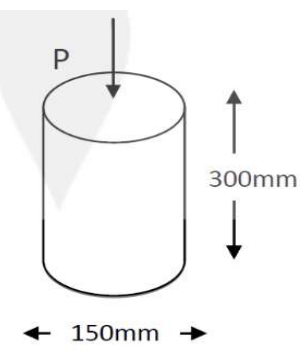

Fig.1. The Test Object

\section{Methods}

\subsection{Mixing planning}

In this study, the researchers applied the method according to the Indonesian National Standard (Indonesia: Standar Nasional Indonesia (SNI)) [17]. In addition, this study was carried out at the Structure and Materials Laboratory of the Civil Engineering Program, Faculty of Engineering, Khairun University, Ternate.

\subsection{Making Test Objects}

In this study, the researchers made test objects in the form of cylindrical concrete in which the fine aggregate was pumice sand and ordinary sand. The test objects made were tested for compressive strength. There were 6 test objects made in this study with a size of $15 \mathrm{~cm} \mathrm{x}$ $30 \mathrm{~cm}$. In detail, 3 test objects were made of pumice sand, while the other 3 test objects were made of ordinary sand. The coarse aggregate for all test objects was crushed stone.

\subsection{The Maintenance of the Test Objects}

The test objects were left for 28 days in a place protected from rain and sun. This was carried out to avoid damage to the test objects until the test was carried out. The compressive strength test of concrete was carried out according to SNI $1974-2011$.

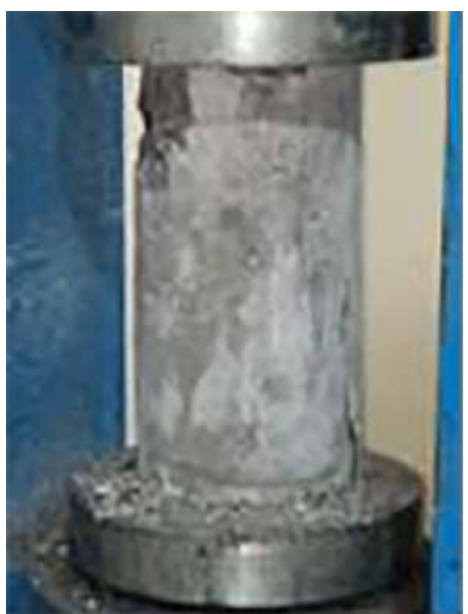

Fig.2. Compressive strength test

\section{Results}

The results of the compressive strength of the test objects are presented in Figure 3.

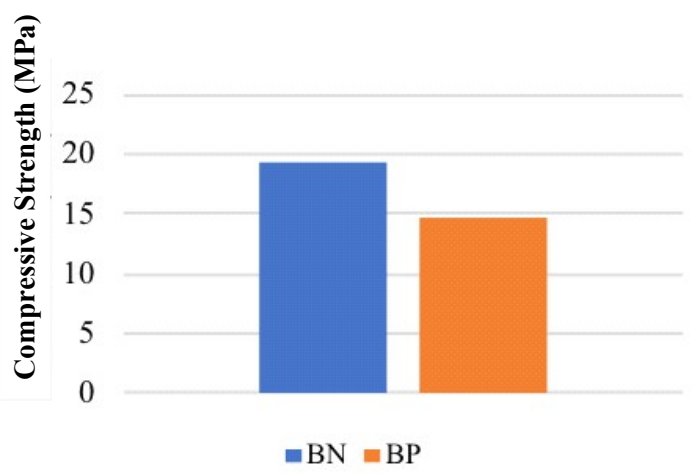

Fig.3. Comparison of the compressive strength of $\mathrm{BN}$ and $\mathrm{BP}$ concretes

Figure 3 showed that the compressive strength of concrete using ordinary sand $(\mathrm{BN})$ as fine aggregate was 19.25 $\mathrm{MPa}$ and the compressive strength of concrete using pumice sand (BP) as fine aggregate was 14.72 MPa. In other words, there was a decrease in compressive strength by $23.53 \%$. This indicates that, for concrete in construction that needs structural strength, the use of ordinary sand as fine aggregate is better than pumice sand.

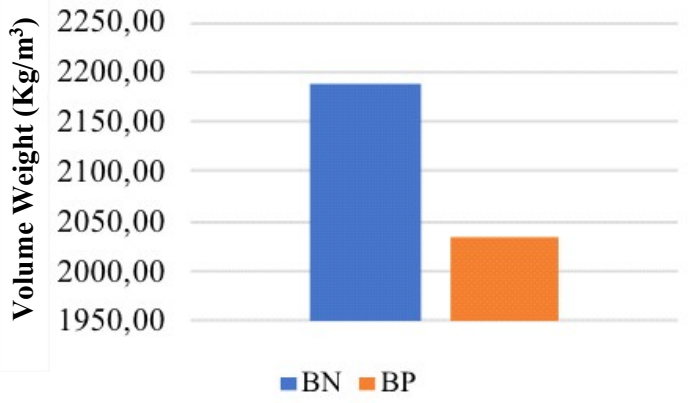

Fig.4. Comparison of the volume weight of $\mathrm{BN}$ and $\mathrm{BP}$ concretes

Figure 4 showed that the volume weight of concrete using ordinary sand as fine aggregate (BN) was 2188.71 $\mathrm{kg} / \mathrm{m}^{3}$ and the volume weight of concrete using pumice sand as fine aggregate (BP) was $2034.67 \mathrm{~kg} / \mathrm{m}^{3}$. In other words, there was a decrease in volume weight by $7.03 \%$. This indicates that, for concrete in the construction that prioritizes the weight of the structure, the use of pumice sand as fine aggregate is better than ordinary sand. The volume weight of concrete using pumice sand is still not categorized in lightweight concrete. The requirement for lightweight concrete is having a volume weight of 1400 $-1850 \mathrm{~kg} / \mathrm{m}^{3}$ [18]. The weight of lightweight concrete cannot be fulfilled because fine aggregate is only a filler material which is relatively less in number compared to 
coarse aggregate which occupies more space in the volume of concrete.

We would like to thank the undergraduate students of the Civil Engineering program and the structural and materials laboratory assistants who have taken a part in this study. This study is part of the authors' thesis entitled "An Analysis of Hole Distance in Flexible Beams Using Pumice Sand as Fine Aggregate"

\section{Conclusion}

The use of pumice sand as a substitute for fine aggregate can reduce the compressive strength of concrete by $23.53 \%$. However, it can reduce the weight of concrete by $7.03 \%$. Therefore, for construction that prioritizes weight, concrete with pumice sand as fine aggregate is better compared to concreate with ordinary sand as fine aggregate.

\section{References}

[1] L. A. Hendratta, "Optimalisasi Sistem Jaringan Drainase Jalan Raya Sebagai Alternatif Penanganan Masalah Genangan Air," Tekno Sipil, vol. 12, no. 61, pp. 9-24, (2014).

[2] T. Turyanto, S. Y. Sri, and A. Nur, "Perencanaan Saluran Drainase Pada Perumahan Bumi Alam Indah Kebun Agung Kecamatan Samarinda Utara," Tek. Sipil dan Arsit., vol. 1, no. 1, pp. 115, (2017).

[3] E. Sutomo, "Efektifitas Drainase Ramah Lingkingan Dalam Mereduksi Genangan pada Kawasan Perumahan Ciampea Kabupaten Bogor," J. Desain Konstr., vol. 16, no. 1, pp. 101-111, (2017).

[4] I. K. Nuraga and I. Suryanti, "Penanganan Sistem Drainase Berwawasan Lingkungan," in Seminar Nasional Ketekniksipilan Bidang Vokasonal VII, (2019), p. 7.

[5] E. S. Wagola, E. A. Muharyanto, A. Sudarman, N. Rumbia, and I. Konong, "Komparasi Kapasitas Lentur Saluran Drainase Beton Pracetak (UDITCH) Tipe Normal dan Inovasi," J. Sci. Technol., vol. 11, no. 1, pp. 29-38, 2020.

[6] E. S. Wagola, R. Djamaluddin, and R. Irmawaty, "Kapasita Lentur Saluran Drainase Beton Pracetak (U-Ditch)," J. Sains dan Teknol., vol. 6, no. 1, pp. 99-103, (2017).

[7] V. A. Noorhidana and E. Purwanto, "Pengaruh Pelubangan Pada Badan Balok Beton Bertulang Terhadap Kapasitas Beban Lentur," J. Rekayasa, vol. 15, no. 2, pp. 151-162, (2011).

[8] A. Gaus, I. Imran, C. Anwar, and N. Sari, "The Effects of The Use of Pumice on Precasct Concrete Mixture For Highway Drainage," Int. J. Civ. Eng. Technol., vol. 10, no. 11, pp. 177-183, (2019).

[9] M. A. Sultan, K. Kusnadi, and M. T. Yudasaputra, "Effect Of Pressure On Making Of Cemen Bricks from Pumice," Int. J. Civ. Eng. Technol., vol. 9, no. 5, pp. 1084-1091, (2018).

[10] A. Gaus, I. Imran, and L. Novianti, "Analisa Kuat Tekan Menggunakan Pasir Apung," J. Sci. Eng., vol. 1, no. 5, pp. 31-40, (2018).

[11] M. A. Sultan, A. Gaus, R. Hakim, and I. Imran, "Review of The Flexural Strength of Lightweight Concrete Beam Using Pumice Stone as of Substitution," Int. J. GEOMATE, vol. 21, no. 85, pp. 154-159, (2021).

[12] A. Y. Muttaqin, "Kinerja Sistem Drainase yang Berkelanjutan Berbasis Partisipasi Masyarakat ( Studi Kasus di Perumahan Josroyo Indah Jaten Kabupaten Karanganyar )," Media Tek. Sipil, pp. 115-124, (2007).

[13] H. Y. Karwur, R. Tenda, S. E. Wallah, and R. S. Windah, "Kuat Tekan Beton dengan Bahan Tambah Serbuk Kaca Sebagai Substitusi Parsial Semen," J. Sipil Statik, vol. 1, no. 4, pp. 276-281, (2013).

[14] S. Sukandarrumidi, Bahan Galian Industri, Ke-3. Jogakarta: Gadjah Mada University Press, 2009.

[15] SNI1974-2011, "Cara Uji Kuat Tekan Beton dengan Benda Uji Silinder," Badan Stand. Nas. Indones., p. 20, (2011).

[16] M. A. Sultan, I. Imran, and F. Litiloly, "Korelasi Porositas Beton Terhadap Kuat Tekan Rata-Rata," Teknol. Sipil, vol. 2, no. 2, pp. 57-63, (2018).

[17] SNI 03-2834, "Tata cara pembuatan rencana campuran beton normal," Badan Standardisasi Nasional. pp. 1-34, (2000).

[18] SNI 03-2461, "Spesifikasi agregat ringan untuk beton ringan struktural," in Badan Standardisasi Nasional, (2002). 